\title{
P-35 SEDIMENTARY ACTIVITY OF THE GUADIARO TURBIDITE SYSTEM DURING THE LAST DEGLACIATION TO HOLOCEN, SW ALBORAN SEA
}

S. LEBREIRO and B. ALONSO

CSIC, Instituto de Ciencias del Mar, Dept. Geologia Marina y Oceanografia Fisica, Paseo Juan de Borbón s/n., 08039 Barcelona, Spain

\section{SUMMARY}

The depositional history of the Guadiaro Turbidite System from the Last Deglaciation to the Holocene is reconstructed by means of a detailed bathymetry, high-resolution seismic profiles (TOPAS system), fine ${ }^{14} \mathrm{C}$ chronological control and grainsize analysis. During the Holocene (last $9.5 \mathrm{kyr}$ ), only three detritic episodes have occurred with decreasing magnitude, capacity and competence to the Presentday: a mass flow (MF1) and a coarse turbidite sequence (TF3) emplaced at c. $9.5 \mathrm{kyr}$, and two turbidity flows of ages 6.6-3 kyr (TF2) and $1.4 \mathrm{kyr}$ BP (TF1). During the interval 6.6-3 kyr contour currents were active at about 600 mwd. The ages of MF1-TF3, TF2 and TF1 coincide with global climate transitions that are well-known in the Alboran Sea: Younger Dryas to Holocene Deglaciation (10.7-9.5 kyr BP), Holocene Optimum Climate to Present-day climate conditions (4 kyr), and shorter scale variations (c. 1.5 kyr). The system has remained inactive for the last $1.4 \mathrm{kyr}$ BP in the canyon and channel domains (as far as $18 \mathrm{~km}$ in distance) and no flow has travelled as far as the modern lobe for the last $9.5 \mathrm{kyr}$ BP (26 km).

\section{INTRODUCTION}

Turbidite systems are of great importance in petroleum exploration because they are one of the major oil deposits in many sedimentary basins world-wide. At a time when petroleum exploration is focusing mainly on deep water projects, the study of the Guadiaro Turbidite System, a small depositional system $(12 \mathrm{~km})$ of the Alboran Sea, may provide analogies for understanding by comparison ancient examples with large fans such as the Mississippi or the Monterey systems, which may not be recognisable in the onland geological record. The Guadiaro Turbidite System is located in the north margin of the westernmost basin of the Alboran Sea (SW Mediterranean Sea), which is defined as a back-arc region. The Guadiaro Turbidite System has developed during the Quaternary; it is fed by the Guadiaro River and shelf sediments that sit on the Marbella margin. This margin is also characterised by a narrow shelf with a break located at $95 \pm 30 \mathrm{~m}$ water depth. The Marbella base-of-slope extends to the Western Alboran Basin, which representsi an unconfined area (Fig. 1). This paper focuses on the study of the architectural elements and sediment transport down the system in order to define its depositional history.

\section{MATERIALS AND METHODS}

This study is based on sixteen gravity cores of $2 \mathrm{~m}$ average length taken in the MAYC96 cruise onboard the Spanish research vessel Garcia del Cid; high-resolution parametric records and TOPAS System bathymetry data collected with the Simrad EM-12 multibeam ecosounder during the MATER11998 cruise; sedimentological data (grainsize, x-rays, detrital versus biogenic components); and ${ }^{14} \mathrm{C}$ dating of 30 samples in a $10-20 \mathrm{mg}$ mixture of $>150 \mathrm{~mm}$ planktonic foraminifer.

\section{RESULTS AND DISCUSSION}

\section{Architectural elements}

The Guadiaro Turbidite System is composed of canyon, channel-levee complex and lobe deposits (Fig. 1). Based on bathymetry, 2 lobes are identified as coexisting in space but not in age. Within the 
canyon edge, four types of facies are described as turbidites, mass flows, contourites and hemipelagites. At the channel-levee complex, four types of facies are found: a) turbidites mainly deposited on the channel floor, which consist of silts, sands and more rarely gravel; b) hemipelagic facies interlayered between the turbidites (e.g. $65-129 \mathrm{~cm}$ in core 8 ); c) levee facies, characterised by centimetre silt lenses or pockets in a sand matrix and vice-versa, with a thickness of $1.3 \mathrm{~m}$; and d) contouritic facies. The lobe deposits contain two types of facies: a) turbiditic facies composed of homogeneous or roughly laminated sand and silt, capped by b) hemipelagic facies, with a greater thickness, up to $190 \mathrm{~cm}$.

\section{Sediment transport down the system: turbiditic/contouritic/mass flow events}

Downcanyon sediment transport, such as mass and turbidite flows, are identified in the canyon edge, channel edge and lobe channel based on visual description, characterisation of sedimentary facies, and 14-C dating (Fig. 2). Alongslope transport is also deduced from contourites, at an approximate depth of 600-680 m. Three main episodes are established, named Detritic Episode 1, which consists of a Turbiditic Flow (TF1); Detritic Episode 2, which consists of a Turbiditic Flow (TF2) and a Contouritic Flow (CF1); and Detritic Episode 3, which consists of a Mass Flow (MF1). Interlayered are three intervals of Hemipelagic Deposits, HF1, HF2 and HF3: The oldest of the three detritic flow sequences is a Mass Flow-Turbidite flow (MF1-TF3) emplaced prior to $8.3 \mathrm{kyr}$ BP; the latest two are of a turbiditic nature, TF1 and TF2, and occurred from 6.6 to $2.9 \mathrm{kyr}$ and 1.5 to $1.3 \mathrm{kyr}$ respectively. TF3 has probably reached site 16, whereas MF1 stopped at site 1 or 3, and TF2 and TF1 did not go beyond site 12 .

\section{Depositional History}

The depositional history of the Guadiaro turbidity system during the Holocene, $9.5 \mathrm{kyr}$, is determined by three gravity flows, MF1, TF 2 , and TF 1 , which lose competence over time, as indicated by detailed grain size analysis. Their emplacement corresponds to periods of shelf instability related to climatic variations in the surface water of the Alboran Sea. These climatic transitions are sea level changes that occurred at 10.7-9.5 Kyr (Deglaciation of the Younger Dryas to the Holocene), at $4 \mathrm{kyr}$ (end of Optimum Climatic and establishment of present day temperate sea surface water conditions) and 1.4 kyr (smaller scale variations, registered in the abundance of planktic biofauna). Alternating with periods of instability, when gravity flows are triggered, there are periods of calm, when the sedimentation changes to hemipelagic, with sedimentation rates of between 21 and $40 \mathrm{~cm} / \mathrm{kyr}$.

Although the Guadiaro deep-sea system has remained inactive for the last $1.3 \mathrm{kyr}$ (TFl age) in the canyon and channel domains, and for the last $9.5 \mathrm{kyr}$ in the most distal lobe, it should still be considered active on a geological time scale. However, the most intense edification of the Guadiaro is prior to the beginning of the Holocene, as is proven by the change from a more competent regime (MF1, TF3) to a finer turbiditic regime (TF2 and TF1). Sediment facies deposited at a water depth of $600 \mathrm{~m}$ reveal the existence of contour currents on the northern slope of the Alboran Sea. The results obtained for the Guadiaro turbidity system reinforce the concept of a close relationship between instability on the continental shelves, canyon activity, building of deep-sea turbidite systems and sea level variations.

gure captions: 


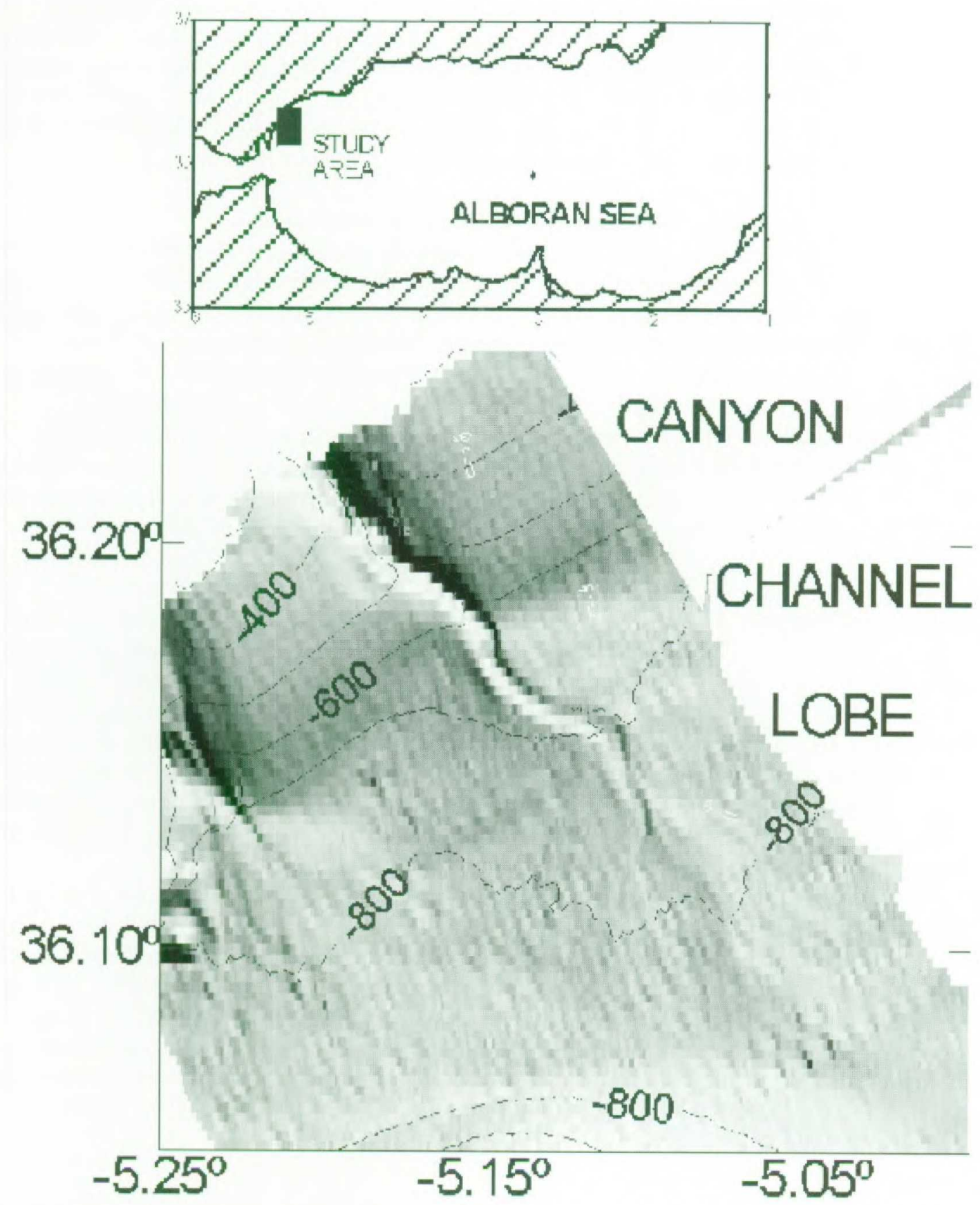

Figure 1. EM-12 multibean bathymetry of the Guadiaro Turbidite System and location of the study area.

Figure 2. Correlation of sedimentary facies and events along cores located in the canyon-channel path. Ages are in yr BP. 


\section{CURRENT DIRECTION}

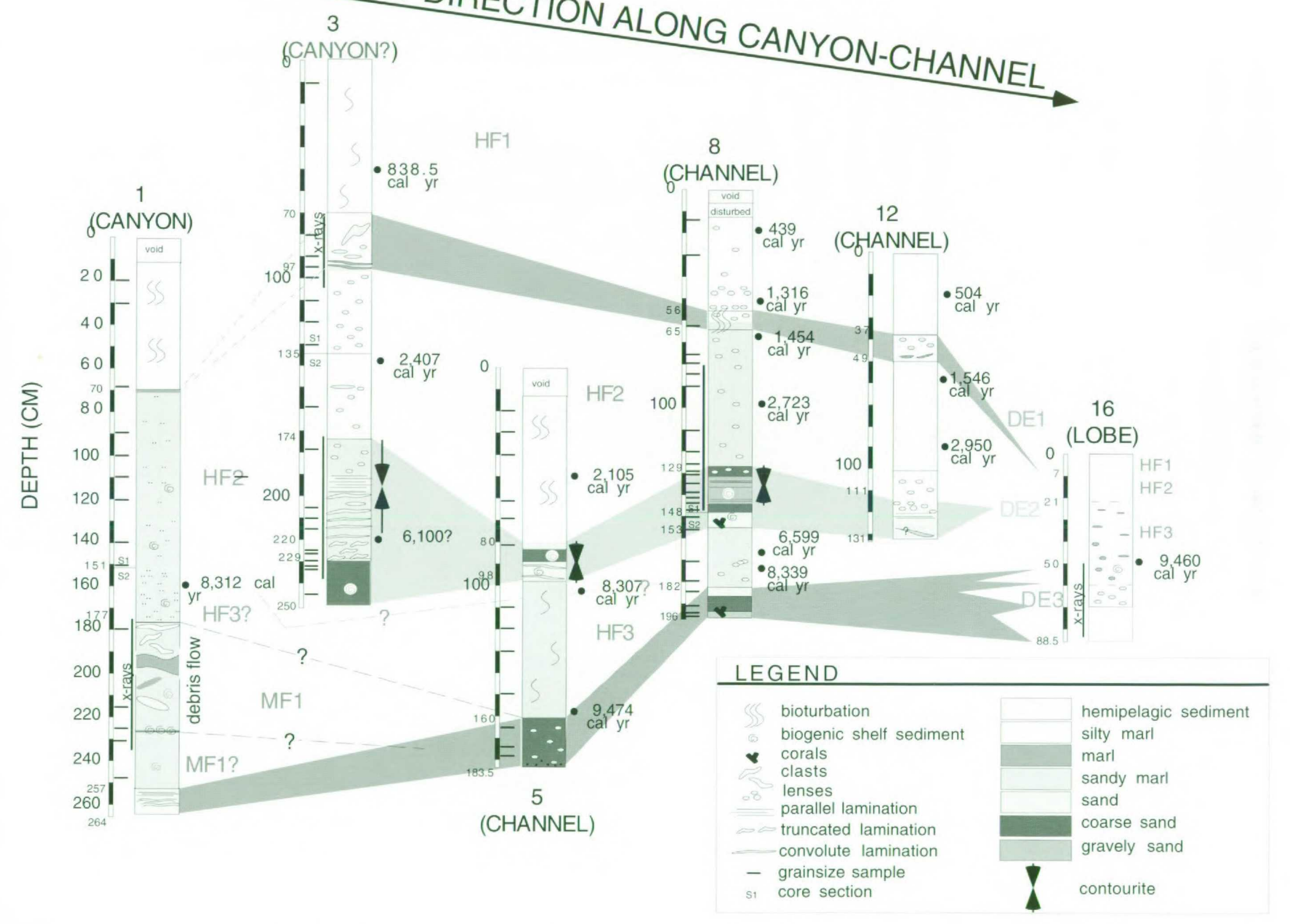

